\section{Evaluating Fertilizer Influence on Overwintering Survival and Growth of Sedum Species in a Fall-installed Green Roof}

\author{
Mary Jane Clark \\ School of Environmental Sciences, University of Guelph, 50 Stone Road East, \\ Guelph, Ontario, N1G 2W1, Canada
}

\author{
Youbin Zheng ${ }^{1}$ \\ School of Environmental Sciences, University of Guelph, 50 Stone Road East, \\ Guelph, Ontario, N1G 2W1, Canada; and Vineland Research and Innovation \\ Centre, 4890 Victoria Avenue North, Box 4000, Vineland Station, Ontario, \\ LOR 2E0, Canada
}

Additional index words. winterhardiness, cold stress, planting season, green roof establishment, mineral nutrition, phosphorus, potassium

\begin{abstract}
Vegetation success on green roofs in northern climates is challenged by extreme weather conditions, especially in winter, and is influenced by season of installation and substrate fertility. Appropriate fertilization with phosphorus (P) and potassium (K) can reduce winter injury for some plant species. The objectives of this study were to identify both the effect of $P$ and $K$ fertilizer rates on Sedum spp. survival over the first winter and the response of Sedum spp. growth to fertilizer rates when applied at installation. In a fall-installed extensive green roof system, survival, growth, and visual appearance of Sedum mats in non-fertilized plots (control) were compared with plots fertilized with 166-13 POLYON ${ }^{\circledR}$ Homogenous NPK plus Minors 3-4 month controlled-release fertilizer at $20.0 \mathrm{~g}$ nitrogen $(\mathrm{N}) / \mathrm{m}^{2}$ either alone or with additional $P$ to total $28.8,54.4$, or $80.0 \mathrm{~g} \mathrm{P} / \mathrm{m}^{2}$ or $\mathrm{K}$ to total $32.5,51.6$, or $70.6 \mathrm{~g} \mathrm{~K} / \mathrm{m}^{2}$. Sedum mats were installed on 8 Oct. 2010 and plants in all plots survived the winter and the next year. During the 2011 growing season, vegetative coverage was not significantly different among any individual fertilized treatments; however, vegetative coverage data combined for all fertilized treatments was larger than the control. Fertilized treatments also showed larger plant height and biomass after one year, taller $S$. acre and $S$. sexangulare inflorescences, increased leaf greenness, and higher visual appearance rankings compared with the control. For individual Sedum species, $S$. album showed the greatest coverage in P-fertilized treatments, and effects on $S$. acre and $S$. sexangulare were treatment-dependent. Application of a controlled-release $\mathbf{N}-\mathbf{P}-\mathrm{K}$ fertilizer, without additional $\mathbf{P}$ or $\mathbf{K}$, can be used to encourage vegetative coverage, plant growth, leaf greenness, inflorescence height, and visual appearance in fall-installed extensive Sedum green roof systems.
\end{abstract}

Green roof installations provide environmental, economic, and aesthetic benefits (Berndtsson, 2010; Oberndorfer et al., 2007) and the success of vegetation on green roofs is critical in realizing these benefits. Ensuring plant survival and growth on green roofs in northern climates is especially challenging during the winter (Boivin et al., 2001; Emilsson

Received for publication 18 May 2012. Accepted for publication 17 Oct. 2012.

This work was financially supported by the Ontario Ministry of Agriculture, Food and Rural Affairs/ University of Guelph Research Program, Landscape Ontario, LiveRoof ${ }^{\circledR}$ Ontario Inc., and Sedum Master.

We thank Sedum Master for providing the plant material, and Greg Yuristy, Katherine Vinson, Linping Wang, Thannushan Nimalendra, and Siobhan Dunets for their technical assistance.

${ }^{1}$ To whom reprint requests should be addressed; e-mail yzheng@uoguelph.ca. growth, and visual rating over controls in green roof systems (Kircher, 2004; Retzlaff et al., 2009; Rowe et al., 2006). Fertilization with $\mathrm{P}, \mathrm{K}$, or both has been shown to enhance cold tolerance of a wide range of plant species, and the type and amount of fertilizer can play a large role in overwintering success (Pellett and Carter, 1981). When fertility remained within an appropriate range for individual species, no winter injury occurred, although there is potential for winter injury if plants are overfertilized or nutrient-deficient (Pellett and Carter, 1981). In general, an adequate supply of $\mathrm{K}$ reduces the risk of frost damage in plants, and $\mathrm{P}$ is required for most plant metabolic processes (Marschner, 1986). For research evaluating plant overwintering in green roofs, the type and rate of fertilizer application varied by study (Emilsson and Rolf, 2005; Getter and Rowe, 2007) or was not reported (Boivin et al., 2001). To the authors' knowledge, no studies have evaluated the influence of fertilizer type or rate in overwintering success for fall-installed green roof systems. Therefore, the objectives of this study were to identify 1 ) the effect of P and $\mathrm{K}$ fertilizer rates on Sedum spp. survival over the first winter when grown as a green roof mat system, installed in fall; and 2) how Sedum spp. growth responds to fertilizer rates when applied at installation to a fall-installed green roof mat system.

\section{Materials and Methods}

Plant material and treatments. A wooden structure containing a Sedum mat green roof system was constructed on the roof outside the fifth floor of the Science Complex at the University of Guelph, Ontario, Canada (lat. $43^{\circ} 31^{\prime} 49^{\prime \prime} \mathrm{N}$, long. $\left.80^{\circ} 13^{\prime} 44^{\prime \prime} \mathrm{W}\right)$. The structure was built from $1.56-\mathrm{cm}$-thick plywood, forming $50 \mathrm{~cm}$ length $\times 50 \mathrm{~cm}$ width $\times 22-\mathrm{cm}$ height boxes, which sloped $3.2 \%\left(1.8^{\circ}\right)$ to a front height of $24 \mathrm{~cm}$, containing a frontfacing 1-cm-wide drainage slit. The 28-box wooden frame was arranged in a grid of 14 boxes long and two boxes wide, oriented with the long sides facing northwest and southeast. The 24 central boxes were used for treatment plots and the two boxes on each end were designated as border plots to reduce edge effects. Each box was painted with one coat of Thompson's WaterSeal Advanced Maximum Strength One-Coat Waterproofer (SherwinWilliams Canada Inc., Vaughan, Ontario, Canada) and lined with a 6-mm Vapor Barrier (Polytarp Products, Toronto, Ontario, Canada) with a $1 \mathrm{~cm} \times 50$-cm slit cut for drainage.

The green roof system was installed inside the lined boxes in the following layers (bottom to top): 5-cm-thick Drainage Board Foam (Sedum Master, Princeton, Ontario, Canada); DELTA $^{\circledR}$-BIOTOP filter fabric (CosellaDorken Products, Inc., Beamsville, Ontario, Canada); 10-cm depth of loose (compressed to $8.75 \mathrm{~cm}$ ) Pre-Engineered Growing $\mathrm{Me}$ dium substrate (Sedum Master); and a PreCultivated SMRM5 Sedum Blanket (Sedum Master). The substrate was comprised of $83 \%$ inorganic (i.e., sand, crushed brick) and 17\% 
organic material (i.e., peat, compost, and coir). The substrate contained $830.00 \mathrm{ppm}$ total $\mathrm{N}$ (i.e., total Kjeldahl $\mathrm{N}$ determined using a classical Kjeldahl digestion and a Skalar segmented flow autoanalyzer and $\mathrm{NO}_{2}$ and $\mathrm{NO}_{3}$ determined using ion chromatography by SGS Agri-Food Laboratories, Guelph, Ontario, Canada), 810.00 ppm total $\mathrm{P}$, and $2200.00 \mathrm{ppm}$ total $\mathrm{K}$ (analyzed using a borate fusion-internal standard and X-ray fluorescence spectrometry method by SGS Laboratories, Lakefield, Ontario, Canada). The plant-available nutrient composition of the substrate was $283.00 \mathrm{ppm}$ $\mathrm{NO}_{3}, 2.67 \mathrm{ppm} \mathrm{P}$, and 263.03 ppm K (analyzed using a saturated paste extraction method by SGS Agri-Food Laboratories). A 10-cm substrate depth is standard in the industry for Sedum mat installations and has not been the cause of extensive winter injury of Sedum spp. in a previous study (Boivin et al., 2001). The Pre-Cultivated SMRM5 Sedum Blanket mats were seeded with a mix of seven Sedum species (i.e., S. album L., S. acre L., S. ellacombianum Praeger, S. pulchellum Michx., S. reflexum L., S. sexangulare L., and S. spurium Bieb. cv. 'Dragons Blood') and grown in the Sedum Master field using standard production practices. Although seven Sedum species were seeded, S. pulchellum was not observed in any plot at installation or during the study. Only S. acre, S. album, and $S$. sexangulare were present in all plots and, therefore, only these three species were included in species-specific observations. Supplemental irrigation water $(\mathrm{pH} 8.0 \pm 0.4$; electrical conductivity $233.0 \pm 38.4 \mu \mathrm{S} \cdot \mathrm{cm}^{-1}$ ) from an on-site catchment pond was applied to the field as needed from 2003 until 27 Sept. 2010. The age of the mats, although older than typical for some suppliers in the industry, was within range for Sedum Master mats. On 29 Sept. 2010, the Sedum mats were cut into $50 \mathrm{~cm} \times 50-\mathrm{cm}$ squares, placed on the growing substrate in the wooden box structure, and each plot was watered by hand with $5 \mathrm{~L}$ of reverse osmosis water. Extra substrate was applied as needed to replace substrate lost in the shipping and handling process.

On 8 Oct. 2010, three replications $(n=3)$ for each of eight fertilizer rate treatments, as outlined in Table 1, were applied to plots evenly by hand in a completely randomized design. Controlled-release N-P-K fertilizer was used as a result of its temperatureinfluenced nutrient release corresponding to plant demand; however, additional granular P was used because it was unavailable commercially in controlled-release form. For 2 weeks after installation, the plots were watered with 1 to $4 \mathrm{~L}$ of reverse osmosis water, as needed, after which time no further supplemental water was applied.

Measurements. Air temperature data were collected by an Integro weather station (Priva North America, Vineland Station, Ontario, Canada) installed on the Science Complex roof, and precipitation data were collected by a Model 7852 Rain Collector II rain gauge (Davis Instruments, Hayward, CA) at the University of Guelph, Guelph, Ontario, Canada. The response of Sedum to fertilizer treatments was evaluated in four areas: winter injury, vegetative coverage, plant growth, and visual appearance. Winter injury was measured for each plot by visually estimating the percent of shoots per Sedum species showing leaf desiccation in the spring (i.e., 8 Apr. 2011). Vegetative coverage per plot was visually estimated by comparing vegetation-covered with non-covered areas for both the proportion coverage per Sedum species and of the plot as a whole after planting and throughout the first growing season (i.e., May to Oct. 2011). Height and width in two perpendicular directions (i.e., $r_{1}, r_{2}$ ) were measured for three representative shoots and inflorescences per species per plot. Elliptical canopy area $(A)$ was calculated for shoots and inflorescences by the following equation: $A=\pi \cdot \frac{1}{2} \mathrm{r}_{1} \cdot \frac{1}{2} \mathrm{r}_{2}$. Visual appearance was qualitatively evaluated in July and Oct. 2011 during and after flowering, respectively. A panel of eight evaluators ranked the appearance of plots on a scale of 1 (very unattractive) to 5 (very attractive). Leaf tissue color was quantitatively evaluated at three locations within each plot using a colorimeter (Minolta CR-310; Minolta Camera Co. Ltd., Osaka, Japan).

Throughout the 2011 growing season (i.e., May to Oct. 2011), root zone $\mathrm{pH}$ and electrical conductivity (EC) levels were monitored monthly by evaluating leachate characteristics using reverse osmosis water in a pour-through analysis modeled after the method by Wright (1986). Collected leachate was evaluated for $\mathrm{pH}$ and $\mathrm{EC}$ using a portable pH and EC meter (Oakton PC 300; Oakton Instruments, Vernon Hills, IL). To quantify aboveground plant biomass, vegetative shoots from all plots were destructively harvested, on 31 Oct. 2011, by cutting back all aboveground growth to soil level, and the fresh weight of the aboveground tissue was measured. All harvested plants were placed in paper bags in a drying oven at $70{ }^{\circ} \mathrm{C}$, and the dry weight was recorded after a constant weight was achieved.

Statistical analysis. All data sets were analyzed using GraphPad Prism Version 5.03
(GraphPad Software Inc., La Jolla, CA). Data sets were tested for normality using the D'Agostino and Pearson omnibus normality test. One-way analysis of variance (ANOVA) was used to determine differences among fertilizer treatment means with a Tukey's multiple comparison analysis. Visual assessment data and data sets among treatments over time were evaluated using a twoway ANOVA with a Bonferroni post-test with repeated measures analysis as necessary. Linear regression analysis was used to analyze the change in proportion vegetative coverage, whereas a Spearman nonparametric correlation was used to compare the change in proportion of vegetative coverage among species. For hue angle, when grouped fertilized treatment data were compared with the control, a $t$ test was used for unpaired data. All data analyses were evaluated using a significance level of $P<0.05$.

\section{Results}

Environmental stress. The air temperature and precipitation conditions encountered by Sedum plants between Oct. 2010 and Oct. 2011 are shown in Figure 1. The greatest cold stress occurred in late Jan. 2011, when the daily maximum $\left(-13.4{ }^{\circ} \mathrm{C}\right)$ and minimum $\left(-21.4{ }^{\circ} \mathrm{C}\right)$ air temperatures reached the lowest point of the winter. Although the daily minimum air temperatures were most often below freezing from December to March, the plants experienced two short unseasonal air temperature changes with warm weather in early January and cold weather in late March. Total monthly precipitation levels were adequate for Sedum plant growth, although much lower in July (i.e., $19.8 \mathrm{~mm}$ ) than the $88.5-\mathrm{mm}$ historical average (Environment Canada, 2012). Leachate $\mathrm{pH}$ values increased over the 2011 growing season for all treatments, and some differences were observed among treatments (Table 2). Leachate EC levels were higher in September than May, June, July, and Aug. 2011 for all treatments except

Table 1. Fertilizer types and rates applied per treatment, percent of vegetative shoots showing leaf desiccation for three Sedum species evaluated on 8 Apr. 2011 and shoot fresh and dry weights of Sedum mat green roof treatments after one year of growth (Oct. 2010 to Oct. 2011).

\begin{tabular}{|c|c|c|c|c|c|c|c|c|}
\hline \multirow[b]{2}{*}{ Treatment $^{\mathrm{z}}$} & \multicolumn{3}{|c|}{ Rate $\left(\mathrm{g} \cdot \mathrm{m}^{-2}\right)$} & \multicolumn{3}{|c|}{ Leaf desiccation $(\%)$} & \multicolumn{2}{|c|}{ Shoot wt (g) } \\
\hline & $\mathrm{N}$ & $\mathrm{P}$ & $\mathrm{K}$ & S. acre & S. album & S. sexangulare & Fresh & Dry \\
\hline Control & 0.0 & 0.0 & 0.0 & $0 \pm 0$ & $0 \pm 0$ & $0 \pm 0$ & $387.6 \mathrm{c}^{\mathrm{y}}$ & $73.3 \mathrm{c}$ \\
\hline $\mathrm{N}-\mathrm{P}-\mathrm{K}$ & 20.0 & 3.3 & 13.5 & $2 \pm 2$ & $10 \pm 3$ & $0 \pm 0$ & $1006.9 \mathrm{~b}$ & $146.3 \mathrm{~b}$ \\
\hline $\mathrm{N}-\mathrm{P}-\mathrm{K}+$ low $\mathrm{P}$ & 20.0 & 28.8 & 13.5 & $3 \pm 1$ & $10 \pm 3$ & $0 \pm 0$ & $1170.0 \mathrm{ab}$ & $176.2 \mathrm{a}$ \\
\hline $\mathrm{N}-\mathrm{P}-\mathrm{K}+$ medium $\mathrm{P}$ & 20.0 & 54.4 & 13.5 & $5 \pm 3$ & $17 \pm 2$ & $0 \pm 0$ & $1092.8 \mathrm{ab}$ & $161.8 \mathrm{ab}$ \\
\hline $\mathrm{N}-\mathrm{P}-\mathrm{K}+$ high $\mathrm{P}$ & 20.0 & 80.0 & 13.5 & $5 \pm 2$ & $19 \pm 8$ & $0 \pm 0$ & $1299.9 \mathrm{a}$ & $170.9 \mathrm{ab}$ \\
\hline $\mathrm{N}-\mathrm{P}-\mathrm{K}+$ low $\mathrm{K}$ & 20.0 & 3.3 & 32.5 & $2 \pm 2$ & $10 \pm 0$ & $0 \pm 0$ & $1117.5 \mathrm{ab}$ & $157.9 \mathrm{ab}$ \\
\hline $\mathrm{N}-\mathrm{P}-\mathrm{K}+$ medium $\mathrm{K}$ & 20.0 & 3.3 & 51.6 & $10 \pm 10$ & $11 \pm 5$ & $0 \pm 0$ & $1018.0 \mathrm{~b}$ & $150.7 \mathrm{ab}$ \\
\hline $\mathrm{N}-\mathrm{P}-\mathrm{K}+$ high $\mathrm{K}$ & 20.0 & 3.3 & 70.6 & $8 \pm 2$ & $17 \pm 6$ & $0 \pm 0$ & $1197.9 \mathrm{ab}$ & $159.4 \mathrm{ab}$ \\
\hline$P$ & & & & 0.65 & 0.13 & & $<0.0001$ & $<0.0001$ \\
\hline Significance & & & & NS & NS & & $* * *$ & $* * *$ \\
\hline
\end{tabular}

${ }^{\mathrm{z}} \mathrm{N}-\mathrm{P}-\mathrm{K}$ refers to $16-6-13$ POLYON ${ }^{\circledR}$ Homogenous NPK plus Minors, 3-4 month controlled-release fertilizer (Agrium Advanced Technologies, Brantford, Ontario, Canada). Low, medium, and high P and K treatments were adjusted using granular 0-46-0 Triple Superphosphate (Sylvite Agri-Services Ltd., Putnam, Ontario, Canada) or 0-0-47 POLYON ${ }^{\circledR}$ Coated Sulfate of Potash, 3-4 month (Agrium Advanced Technologies, Brantford, Ontario, Canada), respectively.

${ }^{y}$ Means in the same column followed by the same letter are not significantly different at $P \leq 0.05$ according to Tukey's multiple comparison test.

$\mathrm{N}=$ nitrogen; $\mathrm{P}=$ phosphorus $; \mathrm{K}=$ potassium; $\mathrm{NS}=$ non-significant. 
for $\mathrm{N}-\mathrm{P}-\mathrm{K}+$ high $\mathrm{K}$ (Table 3). Amongtreatment differences in EC levels were only observed in July 2011 between N-P-K + low $\mathrm{P}$ and the control.

Plant survival and winter injury. Sedum plants survived the winter and rooted into the substrate with zero plant mortality by 25 May 2011. In addition, leaf desiccation winter injury was not observed for shoots of any Sedum spp. in the control. Leaf desiccation did not occur for $S$. sexangulare shoots and was not significantly different among fertilized treatments for either $S$. album or $S$. acre plants (Table 1). Combining data from all fertilized treatments, $S$. album had higher leaf desiccation winter injury than $S$. acre with $13 \%$ of all $S$. album shoots, compared with $5 \%$ of $S$. acre shoots, showing visible leaf desiccation.

Vegetative coverage. The mean proportion of total vegetative coverage at installation

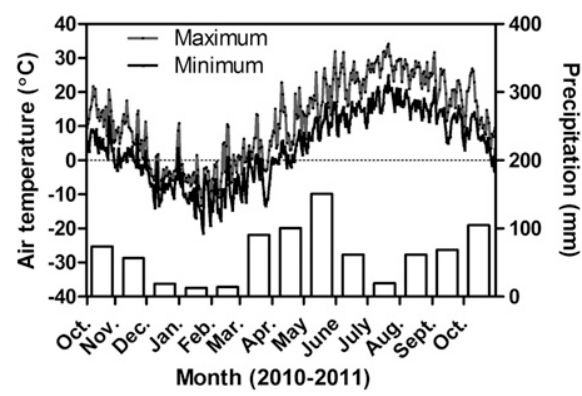

Fig. 1. Daily mean maximum and minimum air temperature (lines) and total monthly precipitation (bars) experienced by Sedum mats from Oct. 2010 to Oct. 2011.
(8 Oct. 2010) was $0.8 \pm 0.01$. By Spring 2011 , total proportion coverage in all fertilized treatments had reached $1.00 \pm 0.00$, whereas coverage in the control was significantly smaller $(0.90 \pm 0.03)$. Over time, no significant differences were observed in proportion vegetative coverage among fertilized treatments; however, the control had significantly smaller proportion vegetative coverage than all fertilized treatments on 25 May, 23 Aug., and 7 Oct. 2011 (Fig. 2). When vegetative coverage was compared among time points, vegetative coverage for all treatments was significantly larger in the spring (25 May 2011) than at installation (8 Oct. 2010), indicating that Sedum plant growth and coverage was possible for all treatments between installation and spring (Fig. 2).

In addition to overall vegetative coverage, fertilizer addition influenced the coverage and composition of three individual Sedum spp. (i.e., S. album, S. acre, and S. sexangulare) as shown in Figure 3. Vegetative coverage of other species (i.e., S. reflexum, S. ellacombianum, and S. spurium 'Dragons Blood') did not notably impact coverage of $S$. album, $S$. acre, and $S$. sexangulare. No significant difference in proportion of vegetative coverage was observed among treatments at installation on 8 Oct. 2010 for $S$. acre $\left(\mathrm{F}_{7,16}=0.32, P=\right.$ $0.94), S$. album $\left(\mathrm{F}_{7,16}=0.47, P=0.84\right)$, or $S$. sexangulare $\left(\mathrm{F}_{7,16}=0.73, P=0.65\right)$. When vegetative coverage among species was compared within plots at installation, S. album covered a significantly larger area than $S$. acre in all treatments and $S$. album had larger coverage than $S$. sexangulare in the $\mathrm{N}-\mathrm{P}-\mathrm{K}+$ low K treatment. S. sexangulare coverage was only significantly larger than $S$. album in the control treatment. When change in vegetative coverage was evaluated between 8 Oct. 2010 and 7 Oct. 2011 for S. album, S. acre, and $S$. sexangulare, change was not significant in the control, N-P-K, or N-P-K + medium $\mathrm{K}$ treatments for any species. S. album coverage in all other treatments showed a significant increase between 8 Oct. 2010 and 7 Oct. 2011 with the greatest increase for $\mathrm{N}-\mathrm{P}-\mathrm{K}+$ high $\mathrm{P}\left(R^{2}=0.99, P<0.0001\right)$ and $\mathrm{N}-\mathrm{P}-\mathrm{K}+$ high $\mathrm{K}\left(R^{2}=0.95, P=0.001\right)$ treatments. $S$. acre coverage significantly decreased between 8 Oct. 2010 and 7 Oct. 2011 in the N-P-K + high $\mathrm{K}\left(R^{2}=0.69, P=0.04\right)$ treatment, but there was no difference in coverage between these time points for $\mathrm{N}-\mathrm{P}-\mathrm{K}+$ low $\mathrm{K}$ or any $\mathrm{P}$ treatment. $S$. sexangulare coverage significantly decreased between 8 Oct. 2010 and 7 Oct. 2011 in the N-P-K + medium P, N-P$\mathrm{K}+$ high $\mathrm{P}$, and $\mathrm{N}-\mathrm{P}-\mathrm{K}+$ low $\mathrm{K}$ treatments $\left(R^{2}=0.77,1.00\right.$, and $0.94 ; P=0.02,<0.0001$, and 0.002 , respectively), but was not significant for the N-P-K + low P or N-P-K + high $\mathrm{K}$ treatments. After one year of growth, considering all treatments, $S$. acre and $S$. sexangulare coverage values were negatively correlated with $S$. album coverage $(R=-0.76$ and $-0.84 ; P=0.029$ and 0.008 , respectively), and $S$. sexangulare coverage was positively correlated with $S$. acre coverage $(R=0.85, P=0.007)$.

Plant growth. At installation, plant height and canopy area were not significantly different among treatments per species. After 7 weeks of growth (24 Nov. 2010), S. album

Table 2. Leachate $\mathrm{pH}$ values and regression results among Sedum mat green roof treatments grown under eight fertilizer treatments during the 2011 growing season.

\begin{tabular}{|c|c|c|c|c|c|c|c|c|}
\hline \multirow[b]{2}{*}{ Treatment } & \multicolumn{6}{|c|}{$\mathrm{pH}^{\mathrm{z}}$} & \multirow[b]{2}{*}{ Regression equation $^{y}$} & \multirow[b]{2}{*}{$R^{2}$} \\
\hline & 31 May 2011 & 28 June 2011 & 26 July 2011 & 23 Aug. 2011 & 27 Sept. 2011 & 24 Oct. 2011 & & \\
\hline Control & $7.18 \mathrm{~b}^{\mathrm{x}}$ & 7.10 & $7.39 \mathrm{c}$ & $7.79 \mathrm{~b}$ & 8.27 & 8.36 & $\mathrm{Y}=4.71+0.0096 \mathrm{X}$ & 0.91 \\
\hline $\mathrm{N}-\mathrm{P}-\mathrm{K}$ & $7.52 \mathrm{ab}$ & 7.03 & $7.50 \mathrm{bc}$ & $8.05 \mathrm{a}$ & 8.24 & 8.52 & $\mathrm{Y}=5.02+0.0090 \mathrm{X}$ & 0.90 \\
\hline $\mathrm{N}-\mathrm{P}-\mathrm{K}+$ low $\mathrm{P}$ & $7.52 \mathrm{ab}$ & 7.49 & $7.75 \mathrm{a}$ & $8.01 \mathrm{a}$ & 8.24 & 8.51 & $Y=5.68+0.0072 X$ & 0.91 \\
\hline $\mathrm{N}-\mathrm{P}-\mathrm{K}+$ medium $\mathrm{P}$ & $7.46 \mathrm{ab}$ & 7.38 & $7.53 \mathrm{bc}$ & $7.97 \mathrm{ab}$ & 8.16 & 8.39 & $\mathrm{Y}=5.36+0.0078 \mathrm{X}$ & 0.81 \\
\hline $\mathrm{N}-\mathrm{P}-\mathrm{K}+$ high $\mathrm{P}$ & $7.55 \mathrm{ab}$ & 7.05 & $7.52 \mathrm{bc}$ & $7.85 \mathrm{ab}$ & 8.20 & 8.38 & $Y=10.73-0.0276 \mathrm{X}+0.00006 \mathrm{X}^{2}$ & 0.81 \\
\hline $\mathrm{N}-\mathrm{P}-\mathrm{K}+$ low $\mathrm{K}$ & $7.52 \mathrm{ab}$ & 7.58 & $7.55 \mathrm{abc}$ & $8.01 \mathrm{a}$ & 8.22 & 8.49 & $Y=9.35-0.0169 X+0.00004 X^{2}$ & 0.92 \\
\hline $\mathrm{N}-\mathrm{P}-\mathrm{K}+$ medium $\mathrm{K}$ & $7.64 \mathrm{a}$ & 7.57 & $7.55 \mathrm{abc}$ & $8.00 \mathrm{ab}$ & 8.26 & 8.55 & $\mathrm{Y}=11.22-0.0288 \mathrm{X}+0.00006 \mathrm{X}^{2}$ & 0.86 \\
\hline $\mathrm{N}-\mathrm{P}-\mathrm{K}+$ high $\mathrm{K}$ & $7.85 \mathrm{a}$ & 7.27 & $7.64 \mathrm{ab}$ & $7.97 \mathrm{ab}$ & 8.32 & 8.44 & $\mathrm{Y}=5.95+0.006 \mathrm{X}$ & 0.49 \\
\hline
\end{tabular}

z $\mathrm{pH}$ measured for leachate using pour-through method. Values are means of three replications.

${ }^{\mathrm{y}}$ Regression equations evaluate the response in $\mathrm{pH}$ from 31 May 2011 to 24 Oct. 2011 per treatment.

${ }^{x}$ Means in the same column followed by the same letter are not significantly different at $P \leq 0.05$ according to Tukey's multiple comparison test.

$\mathrm{N}=$ nitrogen; $\mathrm{P}=$ phosphorus; $\mathrm{K}=$ potassium.

Table 3. Leachate EC values among Sedum mat green roof treatments grown under eight fertilizer treatments during the 2011 growing season.

\begin{tabular}{|c|c|c|c|c|c|c|}
\hline \multirow[b]{2}{*}{ Treatment } & \multicolumn{6}{|c|}{$\mathrm{EC}\left(\mu \mathrm{S} \cdot \mathrm{cm}^{-1}\right)^{\mathrm{z}}$} \\
\hline & 31 May 2011 & 28 June 2011 & 26 July 2011 & 23 Aug. 2011 & 27 Sept. 2011 & 24 Oct. 2011 \\
\hline Control & $175 \mathrm{C}^{\mathrm{y}}$ & $126 \mathrm{C}$ & 129 a C & $114 \mathrm{C}$ & $466 \mathrm{~A}$ & $334 \mathrm{~B}$ \\
\hline $\mathrm{N}-\mathrm{P}-\mathrm{K}$ & $239 \mathrm{BC}$ & $147 \mathrm{C}$ & $175 \mathrm{ab} C$ & $160 \mathrm{C}$ & $452 \mathrm{~A}$ & $361 \mathrm{AB}$ \\
\hline $\mathrm{N}-\mathrm{P}-\mathrm{K}+$ low $\mathrm{P}$ & $219 \mathrm{C}$ & $194 \mathrm{CD}$ & $191 \mathrm{~b} \mathrm{CD}$ & $156 \mathrm{D}$ & $500 \mathrm{~A}$ & $339 \mathrm{~B}$ \\
\hline $\mathrm{N}-\mathrm{P}-\mathrm{K}+$ medium $\mathrm{P}$ & $176 \mathrm{~B}$ & 204 B & $161 \mathrm{ab} B$ & $143 \mathrm{~B}$ & $447 \mathrm{~A}$ & $318 \mathrm{AB}$ \\
\hline $\mathrm{N}-\mathrm{P}-\mathrm{K}+$ high $\mathrm{P}$ & $274 \mathrm{~B}$ & $157 \mathrm{~B}$ & $174 \mathrm{ab} B$ & $146 \mathrm{~B}$ & $506 \mathrm{~A}$ & $275 \mathrm{~B}$ \\
\hline $\mathrm{N}-\mathrm{P}-\mathrm{K}+$ low $\mathrm{K}$ & $207 \mathrm{~B}$ & $214 \mathrm{~B}$ & $171 \mathrm{ab} B$ & $147 \mathrm{~B}$ & $469 \mathrm{~A}$ & $401 \mathrm{~A}$ \\
\hline $\mathrm{N}-\mathrm{P}-\mathrm{K}+$ medium $\mathrm{K}$ & $269 \mathrm{BC}$ & $246 \mathrm{BC}$ & $179 \mathrm{ab} \mathrm{BC}$ & $159 \mathrm{BC}$ & $469 \mathrm{~A}$ & $337 \mathrm{AB}$ \\
\hline $\mathrm{N}-\mathrm{P}-\mathrm{K}+$ high $\mathrm{K}$ & $357 \mathrm{AB}$ & $218 \mathrm{AB}$ & $181 \mathrm{ab} B$ & $150 \mathrm{~B}$ & $448 \mathrm{~A}$ & $288 \mathrm{AB}$ \\
\hline
\end{tabular}

${ }^{\mathrm{z}} \mathrm{EC}$ measured for leachate using pour-through method. Values are means of three replications.

${ }^{y}$ Means followed by the same letter in the same column (lowercase) or row (uppercase) are not significantly different at $P \leq 0.05$ according to Tukey's multiple comparison test.

$\mathrm{EC}=$ electrical conductivity; $\mathrm{N}=$ nitrogen; $\mathrm{P}=$ phosphorus $; \mathrm{K}=$ potassium . 


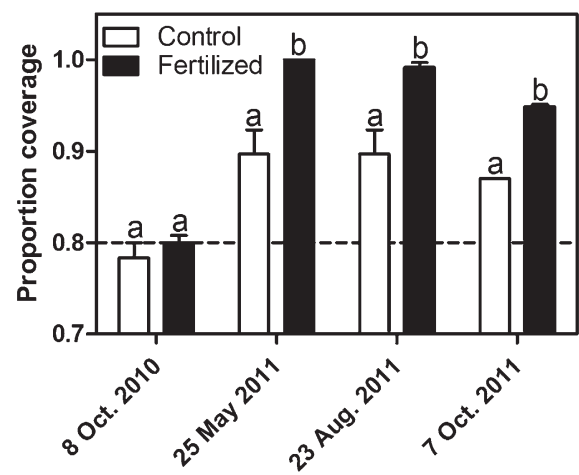

Fig. 2. Proportion total vegetative coverage at installation on 8 Oct. 2010, and over the first ized $(n=21)$ treatments with respect to the mean initial coverage (dashed line). Bars bearing the same letter between treatments for each time point and among time points per treatment are not significantly different at $P<0.05$ according to Tukey's multiple comparison test. Error bars indicate + sE for means per species. growing season, for control $(\mathrm{n}=3)$ and fertil-

shoot height and canopy area in all fertilized treatments, except $\mathrm{N}-\mathrm{P}-\mathrm{K}$ and $\mathrm{N}-\mathrm{P}-\mathrm{K}+$ medium $\mathrm{K}$, were significantly larger than the control (Fig. 4). Additionally, on 24 Nov. $2010, S$. acre shoots in all treatments, except for $\mathrm{N}-\mathrm{P}-\mathrm{K}$ and $\mathrm{N}-\mathrm{P}-\mathrm{K}+$ low $\mathrm{K}$, were significantly taller than the control. No significant difference among treatments was observed for $S$. acre shoot canopy area or $S$. sexangulare shoot height or canopy area on 24 Nov. 2010. The next spring (25 May 2011), shoots for S. album, S. acre, and $S$. sexangulare were significantly taller in all fertilized treatments compared with the control; however, no difference among fertilized treatments was observed. On 25 May 2011, differences in shoot canopy area among treatments were species-specific. $S$. album shoot canopy area on 25 May 2011 was significantly larger in the N-P-K + high $\mathrm{P}$ and all $\mathrm{K}$ treatments compared with the control. On 25 May 2011, S. acre shoot canopy area was significantly larger in the N-P-K + low

\section{S. album}

S. acre

S. sexangulare
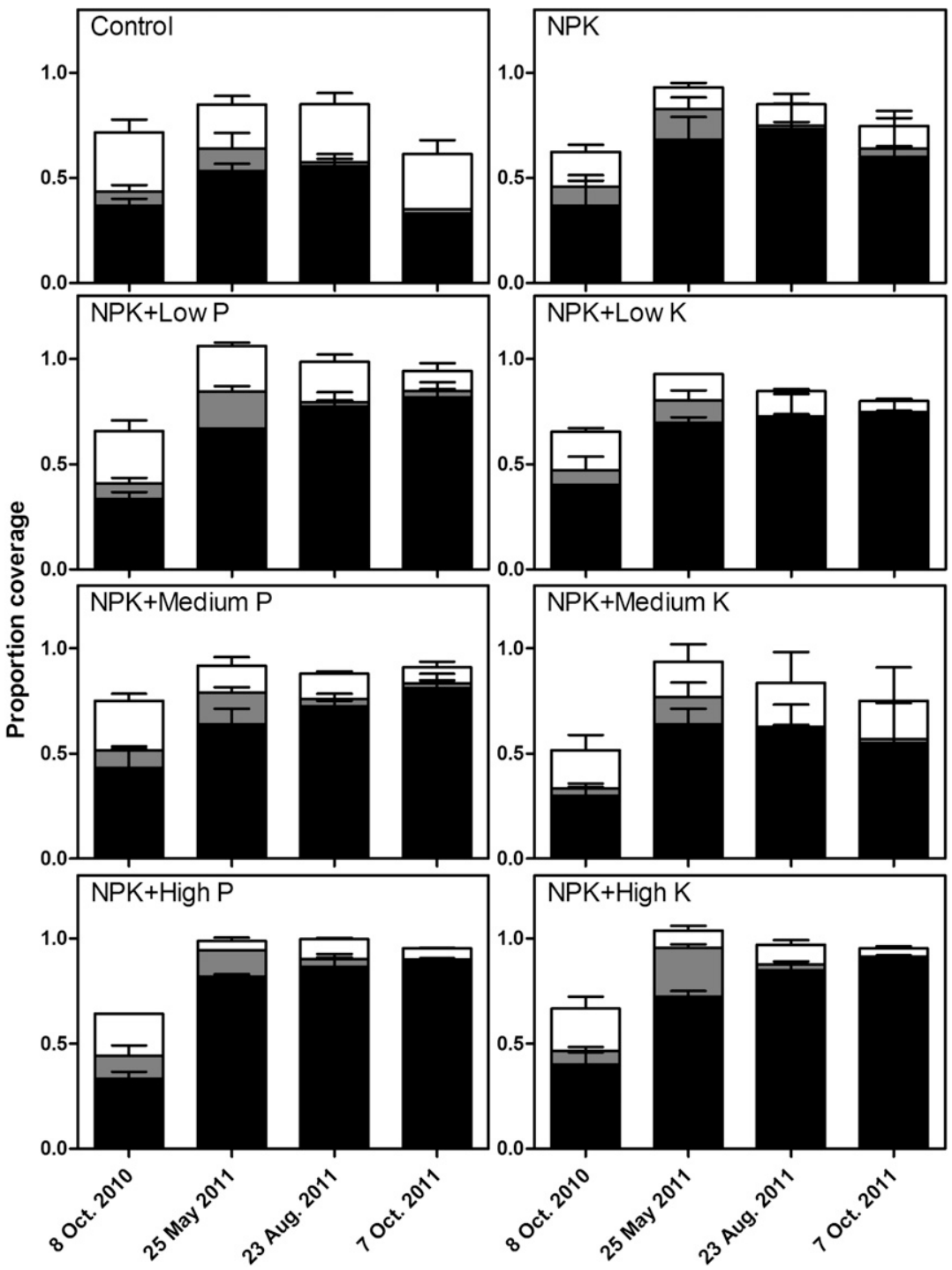

Fig. 3. Proportion vegetative coverage per treatment for $S$. album, $S$. acre, and $S$. sexangulare species grown under eight fertilizer treatments over time $(n=3)$. Error bars indicate + sE for means per species.
$\mathrm{P}, \mathrm{N}-\mathrm{P}-\mathrm{K}+$ high $\mathrm{P}$, and $\mathrm{N}-\mathrm{P}-\mathrm{K}+$ medium $\mathrm{K}$ treatments compared with the control. $S$. sexangulare shoot canopy area was significantly larger in all fertilized treatments, except for the $\mathrm{N}-\mathrm{P}-\mathrm{K}+$ low $\mathrm{P}$ treatment, compared with the control. On 2 Sept. 2011, $S$. album, $S$. acre, and $S$. sexangulare shoots in all fertilized treatments were significantly taller than in the control; however, no significant differences in shoot canopy area among treatments were observed for any species. In addition, we observed desiccation and dieback of leaves on the lower portion of S. album stems in the majority of fertilized treatments beginning in the Summer 2011.

After one year of growth, the fresh and dry weights of total aboveground tissue per plot were significantly lower for the control compared with all fertilized treatments (Table 1). Among fertilized treatments, the N-P-K + high $\mathrm{P}$ treatment had a higher fresh weight than the $\mathrm{N}-\mathrm{P}-\mathrm{K}$ and $\mathrm{N}-\mathrm{P}-\mathrm{K}+$ medium $\mathrm{K}$ treatments and dry weight was significantly higher in the $\mathrm{N}-\mathrm{P}-\mathrm{K}+$ low $\mathrm{P}$ vs. the $\mathrm{N}-\mathrm{P}-\mathrm{K}$ treatment. No other significant differences among fertilized treatments were observed for fresh or dry weight.

Observations of reproductive characteristics among treatments determined $S$. acre and $S$. sexangulare inflorescences in all fertilized treatments were significantly taller than the control, whereas $S$. album inflorescences in all fertilized treatments except for $\mathrm{N}-\mathrm{P}-\mathrm{K}$ and $\mathrm{N}-\mathrm{P}-\mathrm{K}+$ medium $\mathrm{K}$ were significantly taller than the control (Fig. 5). The canopy area of individual $S$. album inflorescences was significantly larger for plants in all fertilized treatments except $\mathrm{N}-\mathrm{P}-\mathrm{K}+$ medium $\mathrm{P}$ and $\mathrm{N}-\mathrm{P}-\mathrm{K}+$ medium $\mathrm{K}$ compared with the control (Fig. 5). S. acre inflorescence canopy area was only significantly larger in the $\mathrm{N}-\mathrm{P}-\mathrm{K}+$ high $\mathrm{P}$ treatment compared with the control. No significant difference in inflorescence canopy area was observed for $S$. sexangulare inflorescences among treatments.

Visual appearance. Observational differences in leaf color were distinct between fertilized and control treatments during Fall 2010. Plants in fertilized treatments remained green longer in the growing season, compared with control plants, which changed from green to red and yellow. When $S$. album leaf color, analyzed by hue angle and measured on Dec. 2010, and Apr., May, July, Aug., Sept., and Oct. 2011, was compared among treatments, plants in the control treatment were significantly different (i.e., within the red to yellow spectrum) in color compared with all fertilized treatments (i.e., within the yellow to green spectrum; Fig. 6). However, no significant difference in color was observed among fertilized treatments.

Visual assessment rankings for overall appearance of green roof plots were significantly different among evaluators in July and Oct. 2011. Analyzed by evaluator, rankings were not different among fertilized treatments, but all fertilized treatments were ranked significantly higher than the control in July and Oct. 2011. The difference in leaf color (i.e., 

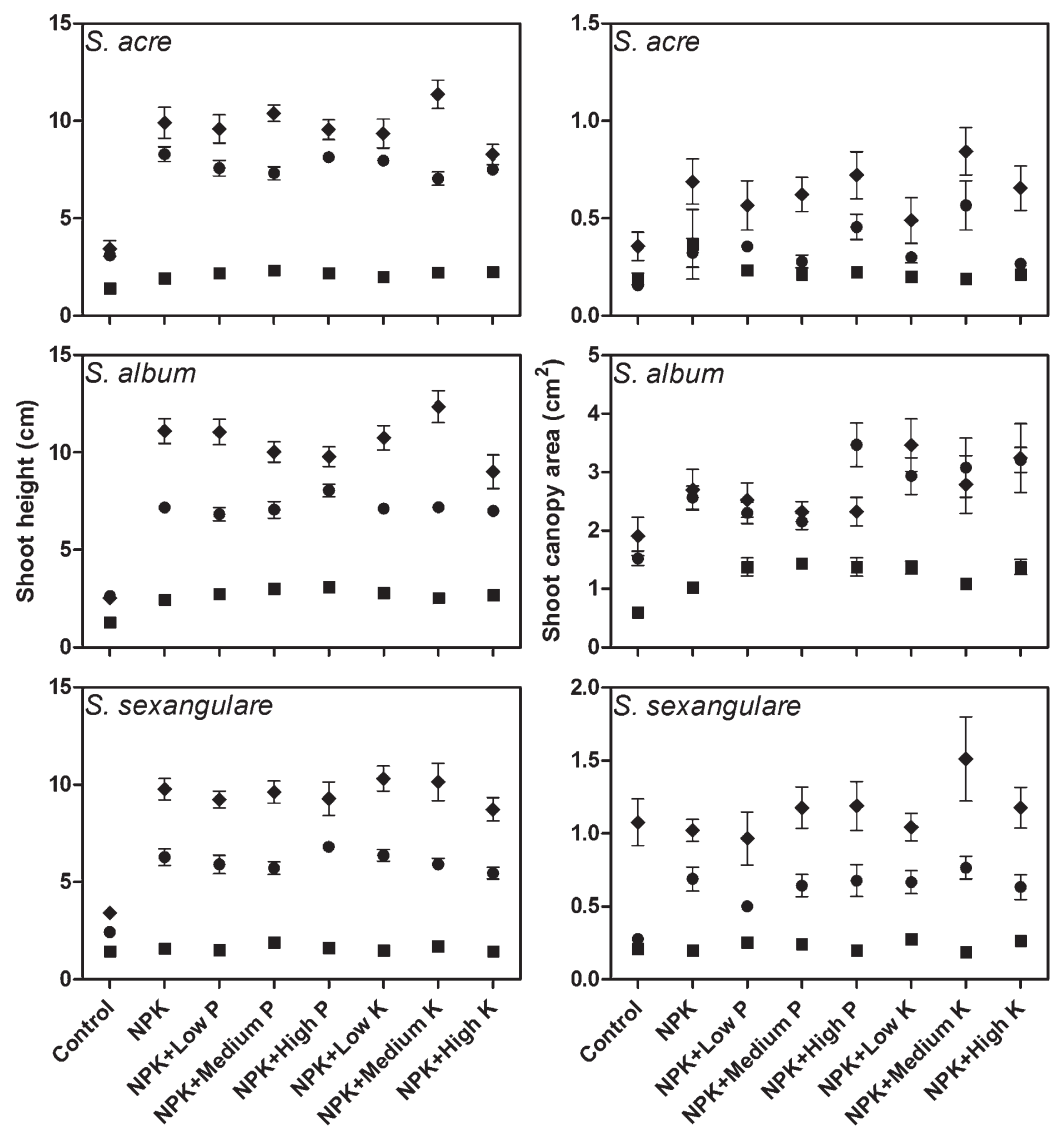

Fertilizer treatment

Fig. 4. Shoot height and canopy area for three Sedum species grown under green roof conditions in eight fertilizer treatments on 24 Nov. $2010(\square), 25$ May $2011(\bullet)$, and 2 Sept. $2011(\bullet)$ after installation on 8 Oct. $2010(\mathrm{n}=3)$. Error bars indicate \pm SE for mean values.

red and yellow in control and green in fertilized treatments) influenced visual assessments for the majority of evaluators, because treatments with greener leaves appeared healthier than those with red and yellow leaves. However, desiccated inflorescence stalks did not negatively influence visual appearance for most evaluators.

\section{Discussion}

The survival and growth of Sedum mats in all fertilizer treatments demonstrated the suitability of this green roof system for use in northern climates, even with a short establishment phase after a fall installation. Although fertilizer was not required for winter survival of Sedum mats, a controlled-release fertilizer without additional $\mathrm{P}$ or $\mathrm{K}$ such as the 16-6-13 POLYON ${ }^{\circledR}$ Homogenous NPK plus Minors used in this study, can be applied after a fall installation to establish vegetative coverage, develop plant biomass in the next season, and enhance leaf greenness of Sedum spp. The addition of $\mathrm{P}$ and $\mathrm{K}$ fertilizers may not have influenced overwintering survival in the current study because Sedum mats were well established before installation (i.e., field grown for seven years). Although environmental conditions during this study included some extreme weather events (i.e., warm and cold fluctuations in Jan. and Mar. 2011, respectively, and low precipitation in July 2011), Sedum mat survival, growth, and flowering showed great resilience. Other green roof systems had lower survival rates when younger plants or Sedum plugs were used (Emilsson and Rolf, 2005). Additional research is needed to expand our limited understanding of green roof performance in northern climates by determining if $\mathrm{P}$ or $\mathrm{K}$ fertilizer applied before winter would increase survival of other green roof plant types (i.e., plugs).

For the duration of the study, the majority of leachate $\mathrm{pH}$ values were within the admissible range (i.e., 6.0 to 8.5 ) for plant growth on green roofs, whereas all EC levels were well below the prescribed soluble salt limit [Forschungsgesellschaft Landschaftsentwicklung Landschaftsbau (The Landscape Development and Landscaping Research Society) (FLL), 2008]. Only the N-P-K, N-P-K + low P, and $\mathrm{N}-\mathrm{P}-\mathrm{K}+$ medium $\mathrm{K}$ treatments had mean $\mathrm{pH}$ values slightly higher (i.e., 8.52, 8.51, and 8.55 , respectively) than the 8.5 range limit. The observed increase in leachate $\mathrm{pH}$ over time may have been influenced by the buffering capacity of the growing substrate. An increase in EC levels from Aug. to Sept. 2011 may have been influenced by a combination of environmental factors.
The proportion vegetative coverage at installation was below full (i.e., 1.00) coverage for a well-established mat as a result of plant disruption during shipping, which caused coverage gaps around the perimeter of plots. However, we observed close to the $80 \%$ coverage required by Forschungsgesellschaft Landschaftsentwicklung Landschaftsbau (The Landscape Development and Landscaping Research Society) (FLL) (2008) guidelines in all plots at installation, and coverage increased for all treatments by Spring 2011. Increased coverage for the control treatment between installation and Spring 2011 could have been caused by plant growth after establishment, encouraged by the mobilization of nutrients in the growing substrate. However, the increased vegetative coverage between installation and Spring 2011 in the $\mathrm{N}-\mathrm{P}-\mathrm{K}$ treatment vs. the control differed from results by Gibbs et al. (2006), who observed no increase in coverage for Sedum plugs with a controlled-release fertilizer application compared with the non-fertilized control. The September planting date and the 10 -week study duration may have impaired nutrient release and use by plants in cool fall air temperatures for Gibbs et al. (2006). We observed full coverage in fertilized treatments for the majority of the 2011 growing season; however, coverage was reduced for all treatments in October compared with May 2011. This coverage reduction was likely the result of flower stem dieback, stems falling over, or low plant water content, which resulted in smaller leaf size with lower air temperatures in October vs. May 2011. Iles and Agnew (1995) reported a decrease in plant water content correlating with increased freezing tolerance in a number of species. Further research is needed to determine if this is a strategy that succulent Sedum spp. adopt to reduce winter injury. Although weed invasion was not a maintenance concern during the study, larger vegetative coverage of fertilized treatments, compared with the control, suggested that weed establishment and weeding maintenance requirements would be lower for fertilized compared with non-fertilized green roofs (Dunnett and Kingsbury, 2008; Getter and Rowe, 2008).

Individual Sedum spp. responded differently to fertilization treatments, especially for proportion coverage and leaf desiccation. The presence of S. reflexum, S. ellacombianum, and $S$. spurium 'Dragons Blood' in some plots did not noticeably influence the relative coverage among $S$. album, $S$. acre, and $S$. sexangulare, likely as a result of differences in plant growth forms. In general, $S$. reflexum had a narrow, upright growth without widespread branching, which did not pose substantial competition for $S$. album, S. acre, or $S$. sexangulare. The large leaves of $S$. ellacombianum and S. spurium 'Dragon's Blood' densely covered areas of some plots but did not influence the relative changes in coverage among S. album, S. acre, or S. sexangulare in the remainder of the plot. Different growth forms among $S$. album, $S$. acre, and $S$. sexangulare caused some overlapping growth, which 


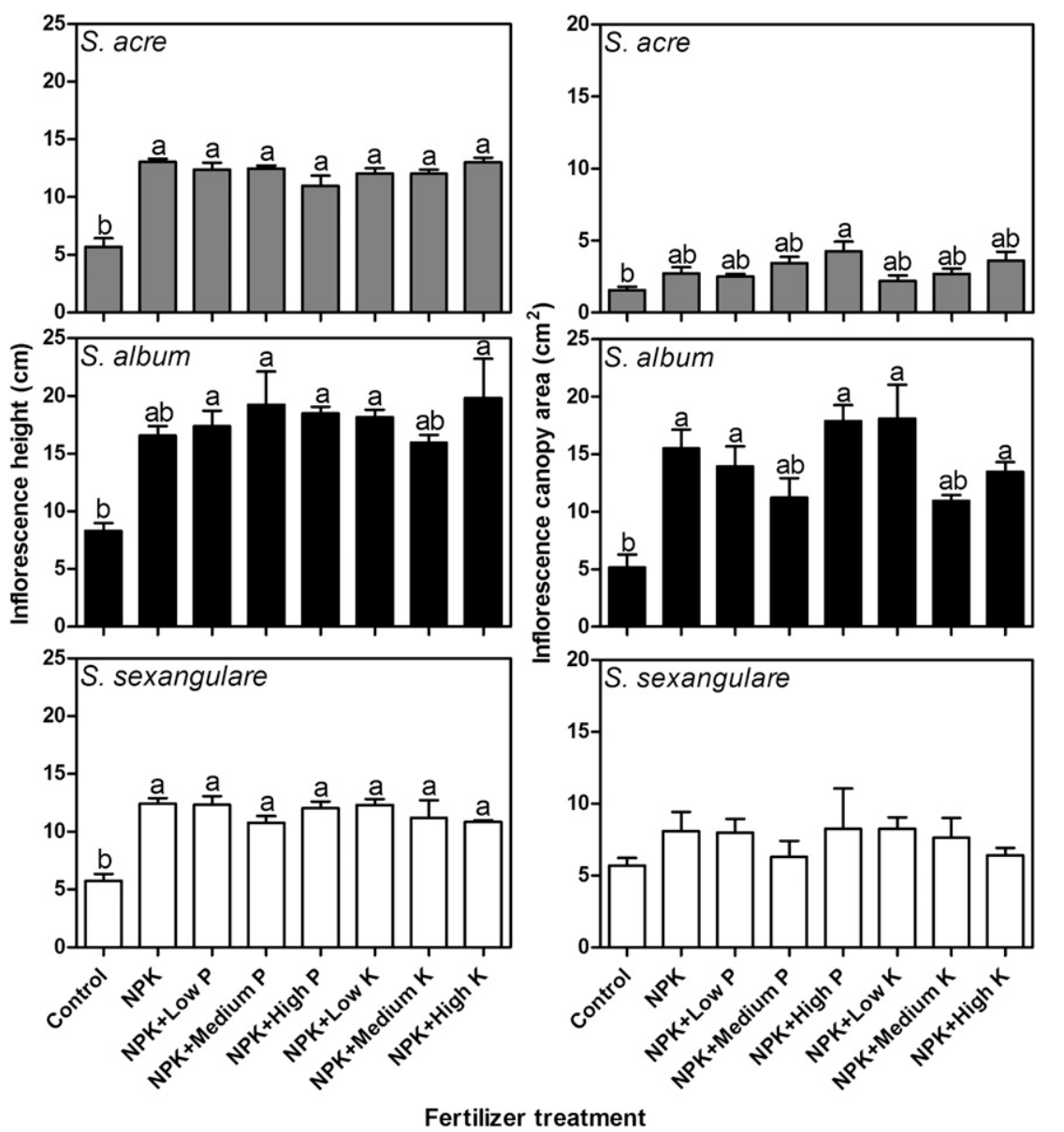

Fig. 5. Inflorescence height and canopy area for three Sedum species grown under green roof conditions in eight fertilizer treatments $(\mathrm{n}=3)$. Bars bearing the same letter are not significantly different at $P<0.05$ according to Tukey's multiple comparison test. Error bars indicate $+\mathrm{SE}$ for means per species.

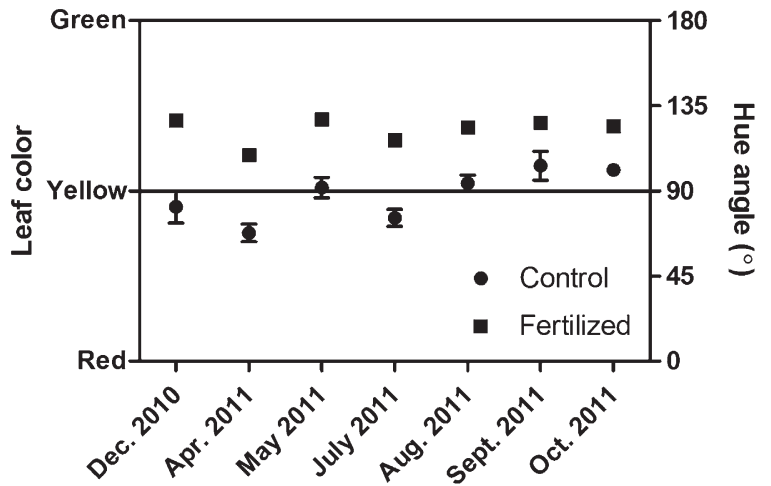

Fig. 6. Leaf color, measured by hue angle, for $S$. album plants in fertilized $(\mathrm{n}=21)$ and control $(\mathrm{n}=3)$ treatments over time. Error bars indicate $\pm \mathrm{SE}$ for mean values.

resulted in depiction of greater than the expected 1.0 coverage in Figure 3 for some treatments when coverage of these species was combined. Durhman et al. (2007) and Monterusso et al. (2005) found S. album spread aggressively, whereas Emilsson and Rolf (2005) noted the hardiness of S. album plants. We also observed this aggressive, hardy growth of $S$. album, because the majority of fertilized treatments resulted in a significant increase in $S$. album coverage by the end of the first growing season. In addition to the increased shoot height over time for $S$. album, $S$. acre, and $S$. sexangulare in all fertilized treatments, compared with the control, the fertilizer-assisted growth of $S$. album appeared to be a factor in the high biomass of fertilized treatments, because $S$. album has a larger leaf size than $S$. acre or S. sexangulare (Evans, 1983). However, in Spring 2011, we observed the highest percent leaf desiccation for $S$. album compared with $S$. acre or $S$. sexangulare. The larger $S$. album leaves may have been more sensitive than
$S$. acre or $S$. sexangulare leaves to air temperature fluctuations in Jan. and Mar. 2011, although after spring growth, leaf desiccation was no longer noticeable. Overall, leaf desiccation may have been caused by a combination of factors including leaf morphology, fertilizer response, or winter air temperature fluctuations. Also, high fertilizer rates can cause brown desiccated tissue in some Sedum species (Barker and Lubell, 2012). We observed such desiccated tissue for lower leaves of $S$. album when vegetation was dense, which occurred in the majority of fertilized plots beginning in Summer 2011.

In the current study, the negative correlation between the vegetative coverage of $S$. album and $S$. sexangulare suggests increased $S$. album growth influenced the decrease of $S$. sexangulare within plots, thus decreasing species diversity over time. Barker and Lubell (2012) and Getter and Rowe (2009) also observed changing species composition within plots over time for certain species combinations. However, when S. album and S. spurium 'John Creech' were grown in combination, final fresh weight proportions were similar to starting cutting fresh weight proportions, although $S$. album growth was not evaluated with additional Sedum species (Barker and Lubell, 2012). As a result of the aggressive nature of $S$. album, individual species performance and among-species competition should be considered when determining green roof species combinations in association with fertilization. Further research is needed to establish fertilizer rates that encourage plant biomass production while minimizing leaf desiccation and maintaining Sedum spp. diversity within green roof systems.

Differences in leaf color, as observed when fertilized treatments were compared with the control, have physiological and aesthetic implications. Physiologically, green leaves have been found to have higher photosynthesis levels than red leaves (Gould et al., 2002), although the authors have not found reports for Sedum in the literature. Photosynthesis influences plant biomass, which affects the albedo and evapotranspiration rate on green roofs and ultimately the functions of roof temperature mediation and water capture (Lundholm et al., 2010). However, further research is needed to quantify the direct influence of Sedum color on green roof performance. Aesthetically, leaf color had a great impact on visual appearance rankings for evaluators. Although rankings varied with personal preference, the majority of evaluators noticed differences among treatments and interpreted the red and yellow leaf color in the control as unhealthy compared with the green leaf color in fertilized treatments. Desiccation of lower leaves for $S$. album in the majority of fertilized treatments did not negatively influence evaluators because the visible upper leaves remained green. Therefore, green roof maintenance strategies should ensure visually appealing green leaves through proper fertilization as it relates to client preferences. The appearance of red and yellow leaves for some Sedum spp. may indicate 
low nutrient levels and, therefore, could be used as a visual cue to apply fertilizer. In October, although dead inflorescence stalks were more noticeable in fertilized compared with control treatments, the stalks did not negatively influence visual appearance for most evaluators, contrary to observations by Emilsson and Rolf (2005).

Overall, Sedum vegetation mats were able to survive and quickly establish, regardless of fertilizer type or rate, after a fall green roof installation in a northern climate. Although fertilizer with or without added P or K was not required for Sedum plant survival over winter, fertilization increased vegetative coverage, plant biomass, leaf greenness, and visual appearance compared with the nonfertilized controls in the next year. Therefore, adding a controlled-release fertilizer without additional $\mathrm{P}$ or $\mathrm{K}$ such as 16-6-13 POLYON ${ }^{\circledR}$ Homogenous NPK plus Minors after a fall installation can be used to realize these benefits. Future work is needed to determine the influence of fertilizers on overwintering for different plant types (i.e., cuttings, seed, or plugs).

\section{Literature Cited}

Barker, K.J. and J.D. Lubell. 2012. Effects of species proportions and fertility on Sedum green roof modules. HortTechnology 22:196-200.

Berndtsson, J.C. 2010. Green roof performance towards management of runoff water quantity and quality: A review. Ecol. Eng. 36:351360.

Boivin, M.-A., M.P. Lamy, A. Gosselin, and B. Dansereau. 2001. Effect of artificial substrate depth on freezing injury of six herbaceous perennials grown in a green roof system. HortTechnology 11:409-412.
Dunnett, N. and N. Kingsbury. 2008. Planting green roofs and living walls. Timber Press, Portland, OR.

Durhman, A.K., D.B. Rowe, and C.L. Rugh. 2007. Effect of substrate depth on initial growth, coverage and survival of 25 succulent green roof plant taxa. HortScience 42:588-595.

Emilsson, T. and K. Rolf. 2005. Comparison of establishment methods for extensive green roofs in southern Sweden. Urban For. Urban Green. 3:103-111.

Environment Canada. 2012. Canadian climate normals 1971-2000. 10 Aug. 2012. <http://www. climate.weatheroffice.gc.ca/climate_normals/>.

Evans, R. 1983. Handbook of cultivated sedums. Science Reviews Ltd., Middlesex, UK.

Forschungsgesellschaft Landschaftsentwicklung Landschaftsbau (The Landscape Development and Landscaping Research Society) (FLL). 2008. Guidelines for the planning, construction, and maintenance of green roofing - Green roofing guideline. Forschungsgesellschaft Landschaftsentwicklung Landschaftsbau, Bonn, Germany.

Getter, K.L. and D.B. Rowe. 2007. Effect of substrate depth and planting season on Sedum plug survival on green roofs. J. Environ. Hort. 25:95-99.

Getter, K.L. and D.B. Rowe. 2008. Media depth influences Sedum green roof establishment. Urban Ecosyst. 11:361-372.

Getter, K.L. and D.B. Rowe. 2009. Substrate depth influences Sedum plant community on a green roof. HortScience 44:401-407.

Gibbs, J., K. Luckett, V. Jost, S. Morgan, T. Yan, and W. Retzlaff. 2006. Evaluating performance of a green roof system with different growing mediums, Sedum species and fertilizer treatments. In: Proc. of Midwest Regional Green Roof Symposium, Edwardsville, IL.

Gould, K.S., T.C. Vogelmann, T. Han, and M.J. Clearwater. 2002. Profiles of photosynthesis within red and green leaves of Quintinia serrata. Physiol. Plant. 116:127-133.
Iles, J.K. and N.H. Agnew. 1995. Seasonal coldacclimation patterns of Sedum spectabile $\times$ telephium L. 'Autumn Joy' and Sedum spectabile Boreau. 'Brilliant'. HortScience 30:1221-1224.

Kircher, W. 2004. Annuals and Sedum-cuttings in seed-mixtures for extensive roof gardens. Acta Hort. 643:301-303.

Lundholm, J., J.S. MacIvor, Z. MacDougall, and M. Ranalli. 2010. Plant species and functional group combinations affect green roof ecosystem functions. PLoS One 5:E9677.

Marschner, H. 1986. Mineral nutrition of higher plants. Academic Press Inc. (London) Ltd., London, UK.

Monterusso, M.A., D.B. Rowe, and C.L. Rugh 2005. Establishment and persistence of Sedum spp. and native taxa for green roof applications. HortScience 40:391-396.

Oberndorfer, E., J. Lundholm, B. Bass, R.R. Coffman, H. Doshi, N. Dunnett, S. Gaffin, M. Kohler, K. Liu, and B. Rowe. 2007. Green roofs as urban ecosystems: Ecological structures, functions, and services. Bioscience 57:823-833.

Pellett, H.M. and J.V. Carter. 1981. Effect of nutritional factors on cold hardiness of plants, p. 144-171. In: Janick, J. (ed.). Horticulture reviews. Vol. 3. Wiley, New York, NY.

Retzlaff, B., J. Gibbs-Alley, L. Swearingin, S. Morgan, V. Jost, and K. Luckett. 2009. Fertility options for green roofs. In: Proc. of Greening Rooftops for Sustainable Communities, Atlanta, GA.

Rowe, D.B., M.A. Monterusso, and C.L. Rugh. 2006. Assessment of heat-expanded slate and fertility requirements in green roof substrates. HortTechnology 16:471-477.

Thuring, C.E., R.D. Berghage, and D.J. Beattie. 2010. Green roof plant responses to different substrate types and depths under various drought conditions. HortTechnology 20:395401.

Wright, R.D. 1986. The pour through nutrient extraction procedure. HortScience 21:227229. 